Terra Brasilis

Terra Brasilis

Revista da Rede Brasileira de História da Geografia e Geografia Histórica

$7 \mid 2016$

Élisée Reclus e a Geografia dos Novos Mundos

\title{
Élisée Reclus e a Histoire d'un ruisseau
}

Os rios também tem história

Élisée Reclus y la Histoire d’un ruisseau: los ríos también tienen historia

Rui Ribeiro de Campos

\section{OpenEdition}

1 Journals

Edição electrónica

URL: https://journals.openedition.org/terrabrasilis/1777

DOI: 10.4000/terrabrasilis. 1777

ISSN: 2316-7793

Editora

Rede Brasileira de História da Geografia e Geografia Histórica

Refêrencia eletrónica

Rui Ribeiro de Campos, «Élisée Reclus e a Histoire d'un ruisseau», Terra Brasilis [Online], 7| 2016, posto online no dia 09 dezembro 2016, consultado o 05 dezembro 2022. URL: http://

journals.openedition.org/terrabrasilis/1777 ; DOI: https://doi.org/10.4000/terrabrasilis. 1777

Este documento foi criado de forma automática no dia 5 dezembro 2022

All rights reserved 


\section{Élisée Reclus e a Histoire d'un ruisseau}

Os rios também tem história

Élisée Reclus y la Histoire d'un ruisseau: los ríos también tienen historia

\section{Rui Ribeiro de Campos}

«Adquiramos, enfim, a liberdade de ser felizes! Necessitamos de fraternidade - de fraternidade entre os povos e as nações, fraternidade entre os

homens.» Reclus

\section{Apresentação}

1 O geógrafo e anarquista francês, Jean Jacques Élisée RECLUS (1830-1905), aos 21 anos já possuía o núcleo central de suas idéias, que carregará por toda a vida. Destacavam-se o fim dos governos, o desaparecimento de fronteiras, para a solidariedade sem distinção de línguas ou "raças" e para a abolição dos privilégios.

2 Antes de fazer da Geografia seu principal ofício, já escrevia sobre problemas relativos à água ocasionados pelo homem. Durante sua estadia nos EUA, no artigo "Fragmento de uma Viagem a Nova Orleans" (1855 ou 1860) fez referência ao sítio urbano;

[...] a menor chuva é suficiente para inundar as ruas, e quando uma tromba d'água se abate sobre a cidade, todas as avenidas e praças se transformam em rios e lagunas. [É aí então que] máquinas a vapor funcionam quase sem descanso para liberar Nova Órleans de suas águas estagnadas e vertê-las, por meio de um canal, no lago Pontchartrain, quatro milhas ao norte do rio. (apud HAESBAERT, 2006, p. 115)

Conforme Reclus, as margens do Mississipi eram represadas por diques e mais elevadas do que as áreas ribeirinhas. Na estiagem, as águas não possuíam mais do que um declive de dez centímetros sobre um curso de $180 \mathrm{~km}$ da cidade até o Golfo do México, o que dificultava o rápido escoamento. A presença de solos úmidos e turfosos faziam com que diversos prédios cedessem. Em plena metade do século XIX, Reclus

[...] já destacava alguns dos problemas que permaneceriam até hoje como características da cidade, como a suscetibilidade as inundações, a pobreza, a exploração religiosa e a criminalidade. Abolida a escravidão, restou a enorme e 
aparentemente insuperável segregação em relação à população afro-descendente.

(HAESBAERT, 2006, p. 117)

Para ele, todos os limites plantados entre as nações eram fruto da ação humana. Era um fervoroso adepto da mestiçagem, criticava Darwin, refutava o darwinismo social, que via como algo produzido pelos dominadores para justificar a opressão e a exploração e era contrário às posições de Malthus. Segundo ele, as condições naturais poderiam ser (relativamente) determinantes quanto menos avançada fosse a organização social. A influência das condições naturais variava de lugar para lugar e de época em época; portanto, era essencialmente antideterminista. Também não aceitava a interpretação dialética, era anticlerical e suas posições eram favoráveis à igualdade de gêneros.

5 Fez boas análises sobre capitalismo, colonialismo, mudanças sociais, urbanização, além de ver o mundo em sua totalidade e em suas dinâmicas. Nas análises dos fenômenos, combinava numerosos fatores para apreender o mundo em toda a sua complexidade. $O$ mundo não seria uma justaposição de elementos, mas um todo sustentado por interações constantes. Grande parte dessas concepções está presente no livro analisado neste artigo.

\section{A história de um pequeno rio}

Se "a dúvida é o travesseiro do sábio", a fé simplória é o travesseiro do pobre de espírito.

(Élisée Reclus)

O livro História de um riacho (1869) se destinava a jovens e adultos motivados pelo movimento de educação popular e não possuía um gênero literário definido: era de divulgação científica, de reflexão sobre a sociedade e também de linguagem poética. Constituía-se de vinte capítulos, com 320 pequenas páginas, cujo personagem principal era um pequeno curso d'água, no percurso de sua nascente até o mar. Os capítulos tratam de água do deserto, torrente da montanha, Gruta e Sorvedouro, ravinas, mananciais do vale, corredeiras e cascatas, sinuosidades, redemoinhos e inundações, margens e ilhotas, passeio, banho e pesca. Além disso, de irrigação, do moinho e da fábrica, do transporte de madeira, da água na cidade, do rio, terminando com o ciclo das águas.

7 Não é um livro para crianças, embora possa ser lido para as mesmas. Utiliza-se de uma terminologia adequada e específica, mas não fornece explicações do significado das mesmas. A título de exemplo: domo, granito, xisto, platôs, quartzo, calcário, cornija, falésia, meandro, limo, clematites (trepadeiras ornamentais), musgos, aluvião, mica, gases sulfurosos, sílica, jaspe, limo, ranhura, opala, aléia, carapulo, glaciares, sílica, zarabatana, diques, mó, eclusas, sulcos, cloaca, aqueduto, ravinas, dutos, bueiro, pólipos, radículas e outros. Diversos locais e vários rios - como Brahmaputra, Iang-Tsé, Orenoco, Amazonas, Mississipi, Sena, Loire, Garone, Reno, Ródano - são citados; entretanto, sem localizá-los. O livro não contém nenhum mapa.

Contudo, não é somente a respeito de um riacho; é também uma análise da sociedade através de sua visão ácrata. $\mathrm{E}$ demonstra sua crença de que, através da ciência, o mundo pode ser melhor, desde que se aprenda a viver em comunidade.

O texto se inicia com a gotícula de água, desde seu surgimento em uma nascente até sua integração no grande rio ou no oceano. Essa agora água, que não conseguimos ver em 
sua totalidade, surge na nascente, que pode ser de vários tipos. A transparência dessas fontes sempre foi, na poesia, um símbolo de pureza, de inocência. Esta água se sujará adiante: "[...]; ela passará sobre as rochas em decomposição e sobre os vegetais em putrefação; ela levará terras com limo e carregará restos impuros espalhados por animais e homens; [...]". (RECLUS, 1869, p.05) ${ }^{1}$ Mas, na fonte, ela é pura, é inspiração para poetas, pintores, escritores e cantores.

10 E mesmo sendo certo que a natureza chegou a dar conselhos aos legisladores, "[...] logo transformados em opressores da humanidade, quanto mais ela não tem feito em favor dos sofredores da terra para lhes restituir a coragem, os consolar na hora da amargura, lhes dar uma nova força na grande batalha da vida." (RECLUS, 1869, p. 09) Se os oprimidos não pudessem recuperar suas energias, as cabeças teriam se curvado sob as mãos de déspotas, as inteligências estariam presas em uma rede de mentiras. Como nas escolas, nas quais muitos professores impõem uma mesma disciplina e mediocridade, nas quais existem pedagogos que se dedicam à obra de modelar as cabeças dos alunos. Felizmente muitos destes mestres que desejavam submeter os outros pelo terror, pela ignorância ou pela rotina, não conseguiram criar um mundo à sua semelhança. A terra não parou de chamar as nações à harmonia e à procura da liberdade. Há necessidade de retirar as maldições jogadas às nascentes pelo padre ignorante da Idade Média. Isto para demonstrar que ele não ficava restrito ao riacho, mas que usava deste tema para também colocar as suas idéias sobre as sociedades.

11 E se propôs a estudar o curso d'água em todo o seu percurso, de cascata em cascata, de meandro em meandro, até o mar, e aprender a utilizar para a irrigação, para a construção de riquezas para toda a humanidade, em vez de deixá-lo destruir lavouras ou perder-se nos lodaçais pestilentos.

12 A Idade Média desaparecia e iniciava uma nova era, mais feliz e mais livre. Aqueles que “[...] se libertavam pelo estudo compreendiam que a ciência, o trabalho, a união fraternal podiam, sozinhos, aumentar o poder da humanidade e fazê-la triunfar sobre o tempo; [...]" (RECLUS, 1869, p. 20-21).

\section{De riacho a rio}

"A natureza não dá saltos." (Reclus)

Para compreender bem a importância das fontes e dos riachos, é fundamental que se volte o pensamento para os locais onde somente algumas fontes afloram. É lá que sabem apreciar mesmo a água. Uma nascente é mais que um símbolo da vida: é a própria vida. Os que vivem em regiões áridas celebram a beleza das fontes; valorizam a pouca água que possuem; sabem que uma chuva transforma, durante algumas semanas, o deserto. Para os que habitam um oásis, este é quase uma prisão (e, às vezes, local de febres por causa das águas paradas); para os que o vêem de longe, é um paraíso.

Entre os grandes agentes naturais, qual o que mais fez pelo desenvolvimento da humanidade?

[...] a história das nações nos mostra [que] a fonte e o riacho contribuíram diretamente para os progressos do homem mais do que o oceano e os montes e qualquer outra parte do grande corpo da Terra. Costumes, religiões, estado social dependem sobretudo da abundância de águas correntes. (RECLUS, 1869, p. 33) 
15 A partir de uma lenda sobre a Fonte da Discórdia, referente aos moradores dos continentes europeu, asiático e africano, afirma perigosamente que a abundância de água seria a verdadeira causa da prosperidade.

As nações da Europa se transformaram nas de moral mais avançada, nas mais inteligentes, nas mais felizes, não porque elas possuíam nelas mesmas algum germe de proeminência, mas porque desfrutavam de uma grande riqueza de rios e de fontes e porque suas bacias fluviais são mais adequadamente distribuídas. (RECLUS, 1869, p. 35)

16 Afirmou que os arianos da Ásia, com história mais antiga, tiveram menos progresso por ser seu território menos irrigado e com grandes desertos; a África, cheia de desertos e de pântanos, foi uma terra deserdada pela falta de rios. Um grave erro, pois se fosse assim a história seria diferente na Ásia Monçônica e na África Equatorial, sem contar com as áreas da América do Sul fartamente irrigadas. Salvava-o um pouco a crença de que a ciência e a solidariedade fariam com que as pessoas compartilhassem seus conhecimentos para fazer um patrimônio comum.

17 São as fontes os pontos de reunião dos pastores nômades; a criação do patriarcado entre os semitas asiáticos aconteceu devido à escassez de nascentes. Já os aborígenes da América desprezavam os riachos, pois os viam correr em grandes e abundantes rios, do mesmo modo que os europeus da região norte, que somente enxergavam os rios em relação aos tonéis ou sacos que conseguiam transportar.

18 A partir dos montes nos quais o riacho nasce, descreve as diferenças do olhar, demonstrando o que se veria se pudéssemos planar como um pássaro ou se estivéssemos em um balão: os limites da bacia, com todos os pequenos vales se reunindo em um vale comum.

19 Escreveu sobre a nascente no verão e no inverno, sobre as nuvens que não deixavam de ser nascente - sob outra forma: chuvisco ou cerração - e que reaparecerão posteriormente em uma fenda das pedras; o mesmo da neve, que deverá rebrotar no solo como fonte. No grande laboratório da montanha, as gotículas sob a neve "penetram no solo até a camada de rocha",

[...] descendo imperceptivelmente ao longo das encostas; elas se aproximam, tornam-se gotas, depois se reúnem umas às outras, que são os filetes líquidos que deslizam subterraneamente por baixo das raízes da relva ou mesmo nas fissuras da rocha subjacente. (RECLUS, 1869, p. 53)

$\mathrm{Na}$ primavera, a neve se transforma em água e incha os regatos. Um pequeno filete de água se transforma em regato e depois em um riacho; escapa dos desfiladeiros e corre mais lento nos largos vales. A cada impulso recebido, a cada afluente, o riacho assume uma fisionomia diferente. Descendo, de silencioso se torna barulhento; em cascatas ou corredeiras seu estrondo se ouve ao longe. Em seu início carrega somente grãos de areia; depois movimenta seixos; rola blocos de pedra, mina na base as paredes de rocha, faz desabar a terra e, algumas vezes, desenraiza árvores (Ibidem, p. 56-57)

20 Na sequência, escreve sobre uma gruta, de onde sai água cristalina - porque ainda não teve tempo de se "sujar" -, adentra à mesma, descreve o que é penetrá-la, as estalactites, concreções calcárias, morcegos, suas salas, estalagmites, ácido carbônico que ajudou a dissolver as rochas calcárias, para lembrar que estas cavernas foram refúgios de nossos ancestrais.

21 As grutas guardam ossos de homens, iniciadores de toda a civilização. Ali se encontram cinzas e carvões das antigas fogueiras, esqueletos rodeados por armas de pedra e 
lanças, que conquistaram o fogo e talharam as primeiras armas. A vida não se torna menos penosa para todos os homens, afirmou ele.

Certamente, não chegaremos ao ponto de dizer que em nossos dias a vida se tornou menos penosa para todos os homens. Uma multidão entre nós, deserdada ainda, vive nos esgotos saídos dos palácios de seus irmãos mais venturosos; milhares e milhões de indivíduos entre os civilizados habitam porões e outros redutos úmidos, grutas artificiais ainda mais insalubres do que as cavernas naturais nas quais se refugiavam nossos ancestrais. Mas, se nós considerarmos a situação em seu conjunto, é preciso reconhecer como foram grandes os progressos obtidos. (RECLUS, 1869, p. 68-69)

Citando que o mineiro vive em galerias que ele mesmo escavou, mas seu pensamento sempre está no alto, que as grutas já foram local de refúgio de ataques e de fogueiras em sua entrada para matar os que estavam dentro, citou que os cadáveres foram escondidos sob as brancas estalagmites: "Símbolo do tempo que modifica todas as coisas, a gota, carregada da pedra que ela dissolveu, fez desaparecer pouco a pouco os traços de nossos crimes." (Ibidem, p. 70-71) Explica como as grutas deixam de existir, como são divididas pela ação das infiltrações e lembra que estas tapeçarias de pedra foram esculpidas pela água.

Um rio que some, um riacho subterrâneo que só se revela por seu ruído, escreveu. E se imagina um átomo para conceber o que acontece. Um abismo em forma de funil, um respiradouro aberto acima do riacho, algo que bebe toda a água que cai ou passa pelo local. Um lugar onde brincou quando criança e que vê agora de modo diferente.

Uma ravina, uma depressão no solo, uma enorme voçoroca, uma grota, é o que descreve no capítulo seis. Um leito muito inclinado, seco em grande parte do ano, escavado no solo, superposto a um rio permanente subterrâneo, no qual há depósitos finos ou não, depositados conforme a força da corrente. "O modesto leito fluvial, de onde a água desapareceu, é ainda tal como foi modelado pela efêmera torrente, e mostra ainda melhor as leis de sua formação pelo fato de que nem uma poça de água o recobre." (RECLUS, 1869, p. 90) E demonstra as características do processo ocorrido.

Nesta grota existe uma natureza livre, sem as lavouras, e uma multiplicidade de animais que ali se refugiam para escapar do grande perseguidor: o homem, que infelizmente também aí os segue. Ali a vegetação é das mais variadas, existem diversos tipos de solo, diferenças de sombra e insolação, de seca e umidade. Como é zona temperada, nesta grande ravina "[...] o fundo úmido no qual não chega jamais um raio de sol possui toda uma outra vegetação; [...]." (RECLUS, 1869, p. 94) Entretanto, não há desordem nesta diversidade, não existe nada artificial ou imposto e sim "[...] a liberdade de atitude e de comportamento, como em uma multidão de homens de todos os países onde cada um se aproxima dos seus." (Ibidem, p. 95) Cada existência é salvaguardada pela aliança de todos.

Os musgos encheram-se de líquido na última inundação e, dilatados como esponjas, preservam até a próxima chuva esta umidade nutritiva. Ali existe um regato pobre e intermitente; contudo, sua ação geológica não é menor e por isso escavou uma enorme fossa, abriu entalhes profundos, esculpiu degraus da cascata etc. "É precisamente em seus menores refúgios que a natureza mostra com maior perfeição sua grandeza" (Ibidem, p. 100).

27 Todos os córregos que se juntam são diferentes uns dos outros, por seu aspecto, pela paisagem que ladeia, pelo volume d'água, por sua oscilação anual. Também possuem 
uma grande diversidade em suas cargas de substâncias minerais. Portanto, tratou da água de modo adequado e não somente como composta de hidrogênio e oxigênio.

Desiguais pelo volume e pela paisagem que as envolvem, as nascentes possuem também uma grande diversidade em seu conteúdo de substâncias minerais, pois por mais pura que a água da fonte pareça ao nosso olhar, ela não é somente, como nos ensina a química, uma combinação de dois corpos simples, [...] ela contém também outras substâncias, seja rolando em seu leito na forma de areia ou de poeira, seja dissolvidas na massa líquida e transparente como ela. (RECLUS, 1869, p. 103-104)

Outra nascente é pródiga em partículas brilhantes, pois suas águas escapam de rochas com micas. Uma outra possui inúmeras moléculas calcárias dissolvidas pela água; ou sal, ferro, cobre e outros metais. Diversas também são suas temperaturas, que dão uma espécie de resumo da vida dos riachos.

Enfim, lá onde a temperatura de uma fonte se aproxima daquela do vapor quente, nós sabemos por isso mesmo que a corrente de água escoava a dois ou três quilômetros abaixo do solo, pois é somente em semelhantes profundidades que a temperatura das rochas é tão elevada como a da água fervente. (RECLUS, 1869, p. 109)

As águas termais dissolvem substâncias nos subterrâneos rochosos e depositam em sua saída. Outras brotam sob a forma de vapores; diversas expelem minérios de ouro e prata do fundo da terra. Algumas águas subterrâneas conseguem dissolver os sustentáculos de uma montanha, provocando tremor de terra. Sabe-se hoje há incorreções em algumas destas afirmações.

Em seu alto curso, quando ainda está descendo as encostas, o riacho é rápido e barulhento, pois ainda vive "o período heróico de sua existência". Corredeiras e cascatas são comuns. Demonstrando um grande amor à natureza, descreve todos os aspectos das corredeiras. Elas são o ensaio das cascatas, que são diferentes: as águas não se espalham muito, passam de modo compacto por uma estreita passagem e caem com grande velocidade. Os caos de espuma, os redemoinhos, as "marmitas de gigante", tudo é descrito.

31 Mas a própria cascata teve um começo e também desaparecerá. Em uma visão próxima aos ciclos de erosão fluvial de William Morris Davis (1850-1934), afirma que "Na superfície da terra, tudo nasce, envelhece e se renova como o próprio planeta." Qualquer vale era bem mais acidentado;

[...] as cascatas que escavaram gradualmente a rocha são transformadas em corredeiras e, depois, em correntes pacíficas. Cedo ou tarde, o riacho escoará como uma vaga uniforme em direção ao mar. No fim, toda desigualdade deverá desaparecer, se a Terra, envelhecendo por um lado, não rejuvenescer por outro. (RECLUS, 1869, p. 130)

o curso de um rio é uma sucessão de curvas; aliás, todas as formas orgânicas apresentam curvas e sinuosidades; nenhuma possui planos regulares, escreve ele. Sempre onde se produz movimento, desenvolvem-se curvas, pois tudo se move desta maneira. Isso para introduzir os meandros, que variam sua forma ao infinito, dependendo da natureza dos terrenos, da violência da corrente de água, dos detritos rolados no fundo dos leitos etc. Olhando uma gota no microscópio, o que se vê são correntes sinuosas e redemoinhos. Usa frequentemente imagens com o uso do microscópio, o que sugere uma atualidade em suas observações.

As massas de água mudam sem parar; as mudanças provocadas são pequenas, exceto quando ocorrem fortes aguaceiros. Descreve a ação das águas nas cheias e afirma que "Estes são os fenômenos que, na série dos tempos, abaixam pouco a 
pouco as montanhas e as estendem em aluviões horizontais sobre as planícies e

sobre o fundo dos mares." (RECLUS, 1869, p. 152)

Descreve com eficiência a ação dos rios nestas cheias, quais materiais carregam, quais que param primeiro e quais permanecem em suspensão, e a própria decantação que ocorre. Escreve sobre como um pequeno rio, durante uma inundação, devasta e destrói; e pergunta: o que são estas cheias e estas baixas de nível comparadas com as mudanças que ocorrem durante as eras?

Como tudo muda na natureza, rios podem se transformar em riachos e vice versa. $\mathrm{E}$ conclui que o riacho que está descrevendo foi no passado um largo e profundo rio, partindo do pressuposto de que o vale por ele atravessado era todo coberto de água. Afirma que era o que diziam os geólogos e não aventa a possibilidade de ter sido a própria mudança de curso a responsável, o que enriqueceria mais o texto. E escreve que o rebaixamento gradual das cordilheiras que bloqueiam umidade, a alteração dos ventos úmidos, a abertura de canais subterrâneos que tragaram as águas e outros, poderiam ter extinguido as nascentes e acabado com o riacho, como ocorrera em desertos da Arábia e da África.

Diz que, se não tivermos medo de permanecer às margens dos rios durante estes fortes aguaceiros, poderíamos ficar no abrigo oferecido pelo tronco de um salgueiro (Ibidem, p. 151); mas aí não teríamos maior perigo de queda de raios?

As águas de um rio não param de trabalhar para modificar seu leito; isso em locais nos quais o ser humano não interveio para regularizar a encosta, limpar o leito ou edificar paliçadas e diques de pedras para proteger as barrancas. Sempre com um aspecto duplo: demolir e carregar, e edificar, depositando os aluviões. Com precisão descreve o processo no fundo e na superfície, e afirma que "ninguém duvida" (Ibid., p. 169) que os desenhos dos mármores e de outras rochas devam-se ao movimento das águas depositando seus aluviões, o que é uma afirmação válida para rochas sedimentares e algumas metamórficas.

A elevação do fundo do leito, os processos decorrentes do aumento ou da diminuição da velocidade das águas, o que acontece com as margens sem proteção, são descritos. Enxergava claramente a importância das matas galerias, escrevendo que as margens que mais resistem são aquelas protegidas por uma barreira de árvores, que se comportam como muralhas. Um dia acaba por apresentar um ponto frágil e será atacada até a derrubada da árvore, que poderá se transformar em uma ponte rústica, na qual se tem a possibilidade de voltar ao tempo de nossa infância.

38 À beira d'água se pode ter um repouso agradável; a visão nos restaura e renova porque o espetáculo se modifica a cada dia, mês ou estação. "Graças à paisagem que muda em torno de nós, nossas idéias também se rejuvenescem; a vida ambiente que nos penetra nos impede de mumificar antes do tempo." (RECLUS, 1869, p. 185) E escreve, em linguagem poética, sobre a paisagem nas quatro estações. E sentimos mais jovens, “[...] pois nós temos plenamente consciência de nossa vida."(Ibid., p. 192)

9 Segundo Reclus, a água compõe grande parte de todos os organismos e poderá auxiliar toda a humanidade no trabalho agrícola. Depois do Sol, que tudo renova com seus raios, do ar que é a respiração do planeta, "a água do riacho é o principal agente da renovação".

"A gotícula de água se transforma em célula de planta, ela se torna um grão, depois o pão e, no corpo do homem, em parcela de vida." (RECLUS, 1869, p. 234) A água cumpre 
sua obra também longe do leito, pois leva a umidade a grandes distâncias, rega as raízes e, durante as cheias, renova a terra. É triste ver os campos invadidos pela inundação, mas esta traz um tesouro para os próximos anos: deposita lama fertilizante que irá sustentar as safras futuras.

O solo da planície, constantemente solicitado para o trabalho do lavrador, se esgotaria rapidamente se os rochedos da montanha, triturados e peneirados pela corrente, não se esparramassem em camadas sobre os campos para renovar a fecundidade. Como mostram as sondagens geológicas, a terra vegetal e o subsolo inteiro são aluviões sucessivamente trazidos de século em século e depositados sobre as bases da rocha: nenhuma planta teria podido germinar no vale se a montanha não se demolisse sem cessar, e se o riacho não carregasse a cada ano estes detritos, para fornecer um novo alimento à vegetação de suas duas margens. (RECLUS, 1869, p. 236-237)

41 E coloca, a seguir, esta questão: como impedir a destruição e, ao mesmo tempo, recolher os aluviões fertilizantes? Alguns sabem como fazer, outros não, o que resulta em desastre para todos. Mas graças aos esforços científicos compartilhados e, se tiver o trabalho associado de todos, isto poderá se transformar. E explica como se pode ter um volume de água que não oscile tanto através de obras de drenagem, adubação e de irrigação, de barragens com comportas móveis, de retirada dos aluviões do fundo das bacias. Isso se os engenheiros encarregados de regularizar o rio saibam fazer uma bacia de alimentação e não um reservatório qualquer, malsão e fétido. 0 grande perigo é se a água for utilizada até a última gota. $\mathrm{E}$ cita algo que já vem acontecendo em alguns rios: sangrados por inúmeros canais de irrigação, podem se extinguir e deixar na secura os seus cursos inferiores (Ibid., p.243).

A água do riacho ajuda na atividade industrial, serve para reduzir o grão em farinha no moinho.

[...], o riacho substitui com sua força aquela dos braços humanos para executar tudo o que faziam antigamente os escravos de guerra ou as mulheres dominadas por seus brutais maridos: ele mói o trigo, quebra o mineral, tritura a cal e a argamassa, prepara o linho, tece os tecidos. (RECLUS, 1869, p. 247-248)

O humilde moinho inspira certa veneração: “[...] graças a ele, milhões de seres humanos não serão mais tratados como animais de carga; [...]. (Ibidem, p. 248) Descreve um antigo moinho e, na sequência, uma fábrica: uma enorme construção, somente com ângulos retos e linhas geométricas, com grandes salas e chaminé semelhante a um obelisco, soltando negras colunas de fumaça. Pilares de ferro, dentes de aço, engenhos de metal que o homem tornou escravos, mas que não pode se distrair sob pena de ser triturado pelo potente organismo. A força que move toda esta engrenagem é a força transformada do riacho.

Os progressos materiais podem ser medidos pelos serviços para os quais os riachos foram requisitados, na agricultura, na indústria e outros. Entretanto, não há mais na Europa a navegação de canoas pelo riacho, exceto como recreação. Vai também se tornar obsoleto o transporte de madeiras pelo rio, pois outros meios de transporte oferecem maneiras melhores.

Canoas existem ainda em locais da América onde caraíbas, por exemplo, ainda utilizam este meio. Ao se referir aos indígenas de Yucatã, afirmou: "A história de sua raça é a de grandes massacres; talvez não exista um de seus ancestrais que, durante três séculos após a conquista das Antilhas, não tenha sido brutalmente massacrado por um ‘civilizador'; [...]” (Ibidem, p. 271). 
46 Na Europa, a destruição gradual das florestas em áreas mais planas fez com que os lenhadores utilizassem as encostas das montanhas. E descreve, com detalhes, a ação destes homens, desde o cortar as árvores até o seu transporte pelos rios. E este tipo de transporte deixará de existir em razão de estradas carroçáveis e de ferrovias. Mas, nas montanhas, as florestas estavam adquirindo um aspecto novo: “[...], pois as árvores, em vez de crescerem em liberdade, são plantadas dispostas em xadrez em distâncias regulares e crescem sob a vigilância de guardas florestais que as cortam antes do tempo" (RECLUS, 1869, p. 282).

47 O capítulo dezoito (A água na cidade) é o mais ligado a políticas ambientais, em uma visão surpreendente para quem vivia na metade do século XIX. Afirma que o riacho deixava de ser livre e passava a ser objeto dos ribeirinhos que, na maioria das vezes, não sabiam como utilizá-lo de modo adequado. Fez críticas às ações européias para controlar os rios com muros mal construídos (que são destruídos pelas correntes), ao desvio de águas que transformam locais baixos em charcos pestilentos, ao ato de jogar lixo no leito e de transformar rios em esgotos. Estas ações modificavam a cor das águas, tornavam-na imunda, viscosa e sem vida (exceto de transmissores de doenças); odores fétidos eram exalados, transformando o local em uma cloaca (Ibidem, p. 284-287).

Os barrancos perderam sua forma natural, se transformando em muralhas perpendiculares; as margens pavimentadas com lajes escorregadias, no lugar de meandros, curvas bruscas. Agora é um esgoto onde a cidade joga seu lixo. Nas cidades a água só é a mesma para os químicos, pois está repleta de imundícies. Cogumelos, ratos; pessoas, somente os trabalhadores de esgoto (que retiram o acúmulo de lama) e grupos de famélicos atrás de qualquer moeda ou objeto ali jogado.

É do rio que as cidades fazem lagos artificiais para que a água possa ser distribuída de bairro em bairro, de casa em casa, através de dutos. Há tubos justapostos, com pequenos rios correndo em sentido opostos: um com água pura que vai para as casas e outro com a água suja que sai delas e vai continuar poluindo os rios. Mas sabia que, dependendo do trajeto, após a cidade o rio poderia se decantar, se "purificar". Para ele, na cidade do futuro, os homens farão o que a ciência aconselha.

50 Ao sair da cidade, as águas do esgoto, aspiradas por máquinas, [...], se dirigirão para um largo reservatório abobadado no qual as imundícies arrastadas se misturarão em um líquido lamacento. Aí outras máquinas apoderar-se-ão da massa fétida e a lançarão por jatos em dutos, em forma de raios, nas diversas direções sob o solo dos campos. Aberturas feitas à mesma distância sobre os aquedutos permitirão espalhar os dejetos em quantidades medidas previamente sobre todos os campos empobrecidos que necessitam regenerar por adubação. Esta lama corrente, que seria a morte das populações, se ela devesse permanecer nas cidades [...], se torna, ao contrário, a própria vida das nações, pois se transforma em alimento para o homem. (RECLUS, 1869, p. 295-296)

51 A água, que servia para todas as sujeiras, agora estará limpa pelas operações feitas pelas raízes e radículas; pode voltar para a cidade para limpar ou para o rio. Se a água for limpa a partir da primeira cidade, o riacho pode retomar sua beleza. Preocupações ainda raras no século XIX; comum para quem tinha em vista outro futuro.

Ele diferencia rio de riacho. Um rio é um conjunto de riachos, visíveis ou invisíveis; é maior e espanta por seu volume, sua força, mas permanece semelhante. 0 riacho é mais 
pitoresco, mais surpreendente. É superior ao rio pelo imprevisto de sua marcha, pela beleza de suas margens, pela relativa impetuosidade de suas águas.

É por seus agentes mais frágeis que a natureza revela com a maior perfeição sua força. Vista no microscópio, a gotícula que se formou debaixo da rocha executa uma obra geológica proporcionalmente bem maior do que aquela do oceano sem limites. (RECLUS, 1869, p. 299-300)

Entretanto, segundo Reclus, até aquele momento o homem tinha sabido utilizar melhor as águas dos riachos do que as dos grandes rios; estas eram pouco utilizadas para a indústria, para a irrigação etc. Eram usadas para flutuar embarcações e esta utilidade estava diminuindo em razão das estradas de rodagem e de ferro. Era necessário que o homem deixasse de temer as enchentes e que regulasse o caudal segundo suas necessidades. Contudo, mesmo quando a ciência fornecer recursos para domesticar os rios, as pessoas permanecerão impotentes enquanto permanecerem isoladas em seus trabalhos, sem se associarem (Ibid., p. 301).

Um rio mistura tudo o que recebe de suas torrentes anteriores; após receber rochas trituradas das cadeias montanhosas, cria novas formas de relevo. Uma planície em seu baixo curso é um presente do rio, pois anteriormente fazia parte de montanhas.

Como nos tempos passados, terra e água se confundem e formam novos tipos de paisagens. Por todos os lados se está cercado por terras em formação. Possuía uma visão de mudança, tanto social quanto geológica, impressionante para a sua época. Escrevendo sobre uma área plana, afirmou: todo o espaço abrangido pelo olhar era antigamente mar. $\mathrm{O}$ rio o cobriu pouco a pouco, embora o solo depositado ainda não esteja firme (Ibid., p. 306).

Todas as lamas "[...] que manteve em suspensão são repelidas pelas ondas para o leito fluvial; não podendo seguir adiante, elas se depositam no fundo e formam assim uma espécie de muralha móvel servindo de limite temporário entre os dois elementos em luta." (RECLUS, 1869, p. 307) Esse banco que obstrui a boca do rio não cessa de se deslocar, para se reorganizar mais adiante. "De século em século, de ano em ano, de dia em dia, este rio, que parecia impotente contra o imenso mar, não obstante estende-se sobre ele, e é possível calcular o quanto ele avançará em certo período, de tanto que sua marcha é uniforme." (Ibidem, p. 308) Esta vitória sobre o oceano foi conseguida por milhares de pequenos riachos; foram eles que "rasparam" as rochas, que rolaram sedimentos, que trituraram cascalhos e transportaram areias. São eles que, pouco a pouco, abaixam os continentes para espalhá-los sobre o mar.

Termina o livro escrevendo sobre o ciclo das águas, lembrando que o mar é composto por milhares de riachos que nele deságuam. Esse mar transporta a água de todos os rios de uma extremidade à outra. Ela pode ser absorvida por uma alga ou por um organismo animal ou transformar-se em vapor e subir invisível no espaço.

[...]; o grande mar de umidade, mantido em suspensão na atmosfera, está destinado quase todo a cair sobre o globo terrestre. As inumeráveis moléculas de vapor permanecem invisíveis enquanto o ar não está saturado: mas que o aumento da umidade ou a diminuição da temperatura determinam o ponto de saturação, logo as partículas de vapor se condensam, elas tornam-se gotículas de nevoeiro ou de nuvem e se aglomeram com milhões de outras moléculas em imensas quantidades suspensas nas alturas do ar. Muito pesadas, essas nuvens derramam-se em chuvas e em aguaceiros no oceano de onde saíram, ou então, empurradas pelos ventos, deslocam-se por cima dos continentes, aonde vão se chocar [...]. Precipitam-se, seja como chuva, seja como neve; depois, gotas e flocos, divididos ao infinito, penetram na terra [...]. Por muito tempo a água permanece escondida, depois reaparece à luz 
em alegres nascentes, e recomeça sua viagem rumo ao oceano pelos leitos inclinados dos riachos, dos ribeiros e dos rios. (RECLUS, 1869, p. 312-313) riacho que se afasta, nós mudamos a cada instante; nossa vida se renova de minuto em minuto, e se nós cremos permanecer nós mesmos, isto não passa de uma pura ilusão de nosso espírito" (RECLUS, 1869, p. 315).

\section{A sua visão da sociedade}

\section{“L'anarchie c'est l'ordre sans le pouvoir." (Élisée} Reclus)

Reclus, no prefácio de "A Conquista do Pão" (de Kropotkin), afirmou: “[...] enquanto na terra 'houver pobres', é um gracejo de mau gosto, é uma ironia cruel dar o nome de 'sociedade' a este conjunto de seres humanos que se odeiam e se despedaçam como feras encerradas numa arena." (In: KROPOTKINE, 1975, p.12) E afirmou ainda:

Mas, a reivindicação de todos os bens usurpados à comunidade, isto é, a expropriação, só o comunismo anárquico a pode realizar. E para isso teremos que destruir o governo, rasgar as leis, repudiar a sua moral, desobedecer à autoridade $\mathrm{e}$ seguir os estímulos da nossa própria iniciativa, agregando-nos segundo as afinidades, os nossos interesses, o nosso ideal e a natureza dos trabalhos a realizar. (In: KROPOTKINE, 1975, p. 13)

60 Em A evolução, a revolução e o ideal anarquista (1898), conceituou evolução e revolução, denunciou preconceitos, hipocrisias, analisou grandes períodos e fatos históricos, do passado até o presente, demonstrou que defensores da Reforma agiram do mesmo modo que os católicos e que

É em nome da liberdade, da igualdade e da fraternidade, que se cometem, doravante, todas as maldades. Era para emancipar o mundo que Napoleão fazia seguir atrás dele um milhão de degoladores; é para fazer a felicidade de suas caras pátrias respectivas que os capitalistas constituem as vastas propriedades, constroem as grandes fábricas, estabelecem os poderosos monopólios que restabelecem, sob uma nova forma, a escravidão de outrora. (RECLUS, 2002, p. 36)

61 E insistiu na necessidade do verdadeiro revolucionário estudar e conhecer os fatos: "Não aceitamos verdade promulgada: fazemo-la nossa, antes de mais nada, pelo estudo e pela discussão, e aprendemos a rejeitar o erro, tivesse ele mil selos de garantia e certificados." (Ibidem, p. 52) Segundo ele, a história mostrava que toda obediência era abdicação e que toda servidão era morte antecipada; mas também que séculos de descobertas foram sempre aqueles em que os poderes religiosos e políticos se encontravam enfraquecidos por competições e que em sua época a característica básica era a onipotência do dinheiro.

Criticou a instituição "justiça", o "exército", as palavras como "ordem", "patriotismo" ou "paz social" e os partidos que conquistavam ou desejavam o poder, pois os revoltados de ontem se tornavam os conservadores do dia seguinte. Não poupou nem os socialistas: "Certamente, os socialistas, tornados os senhores, procederão e procedem da mesma maneira que seus antecessores republicanos: [...]" (Ibidem, p. 84).

Condenou a educação realizada nas escolas por religiosos, por serem os mesmos inimigos da ciência e ocultadores de fatos. Afirmou que era fora da escola que mais se instruía, mas valorizou a escola com diferentes concepções de educação. Mas a libertação cabe a cada um, principalmente aos que se sentem oprimidos e que são 
solidários. "Para combater é preciso saber." "É nas cabeças e nos corações que as transformações devem realizar-se, antes de estender os músculos e transformar-se em fenômenos históricos." (Ibidem, p. 45) Por isso que a primeira condição para a obtenção de triunfo é se livrar da ignorância.

\section{coletivista fundado no apoio
possibilidades de retrocesso.} riachos carregam partículas de ouro quantidades, atrairiam uma multidão, tudo seria atacado com enxadas e picaretas, cabanas surgiriam. "Pode ser que o país, se tornando mais rico, mais populoso e mais próspero, se transformasse também em um lugar mais instruído e mais feliz; [...].” (RECLUS, 1869, p. 104-105) doentes, ávidos por saúde, utilizam o que saem das nascentes, aspiram os gases que escapam, banham-se na lama negra que formam.

Quando a ciência tudo esclarecer e o homem, sabendo perfeitamente qual deve ser seu gênero de vida, souber, além disso, quais águas, qual atmosfera convêm à cura de seus males, então nós poderemos desfrutar da plenitude de nossos dias e prolongar nossa existência até seu término natural, contanto que nosso estado social não continue sendo o de nos odiarmos e nos matarmos uns aos outros. (RECLUS, 1869, p. 117)

No décimo segundo capítulo diz que passar acompanhando o riacho, para apreciar sua beleza, é muito bom, exceto para aqueles que passeiam só por ociosidade e que vêem em tudo motivos de tédio.

Para saborear tudo o que oferece de delicioso um passeio ao longo de um riacho, é preciso que o direito a passear sem destino tenha sido conquistado pelo trabalho, é preciso que o espírito fatigado tenha necessidade de recuperar sua atividade à vista da natureza. O trabalho é indispensável para quem deseja gozar do repouso, da mesma maneira que o lazer diário é necessário a cada trabalhador para renovar suas forças. A sociedade não deixará de sofrer, ela estará sempre em um estado de equilíbrio instável, enquanto muitos homens, condenados em tão grande número à miséria, não tenham todos, após cada tarefa cotidiana, um período de repouso para regenerar seu vigor e se manter assim em sua dignidade de seres livres e pensantes. (RECLUS, 1869, p. 183)

E pergunta: de quem é este riacho? Nós nos dizemos proprietários, como se fôssemos os únicos a aproveitá-lo. Mas ele também pertence a todos os seres que o povoam e dele 
tiram a substância, a vida; é dos peixes, dos mosquitos, das árvores. "Cada um, na sua luta pela existência, vive à custa de seus vizinhos." (Ibid., p. 197) E termina este capítulo com um trecho que agradaria alguns defensores do meio ambiente:

Quanto a mim, gostaria de fazer com todos um bom acordo, eu me esforço para respeitar a flor e o inseto, e, todavia, quantos massacres faço sem me aperceber! Destruo mundos do infinitamente pequeno quando estendo sobre a grama minha pesada massa; eu arruíno florestas, deflagro cataclismos na história de uma colônia imperceptível ao subir em uma árvore para balançar minhas pernas acima do riacho. (RECLUS, 1869, p. 197-198)

71 No capítulo treze (O Banho) fala sobre o ato de banhar-se, tanto no inverno quanto no verão. Fala das vantagens de se lançar no rio e de como cada um, "se as convenções e as falsidades da vida não corromperam inteiramente" (Ibidem, p. 205), pode encontrar alegria neste ato. A natureza nos oferece seduções das quais é necessário desconfiar; ela pode nos levar para longe do campo de batalha, do combate pela justiça e pela liberdade.

Entretanto, um dos prazeres do banho em um riacho é deixar nossas "odiosas roupas", deixarmos de lado, pelo menos, uma parte dos preconceitos do ofício, pois de tudo esquecemos, pelo menos por uma hora. Relatou quando viu soldados se banhando e afirmou: "Nada de obediência passiva, nada de abdicação de sua própria pessoa; [...]." (Ibidem, p. 210)

Sua visão era também de respeito ao ambiente para uso do homem. No capítulo catorze (A Pesca) escreve que um riacho também é um reservatório de alimentação, pois alimenta plantas, peixes e serve à nossa subsistência. Entretanto, eram eles bem mais ricos em peixe. 0 homem encontrou meios de destruir muitos deles.

Em sua ávida imprevidência, ele foi capaz de exterminar por inteiro espécies que outrora viviam nos riachos. Ele não somente se serviu de redes que barram a massa d'água e aprisionam toda a população, como também se serviu de veneno para destruir de uma só vez multidões e fez uma última captura mais abundante do que as outras. (RECLUS, 1869 , p. 216)

Os verdadeiros pescadores, os de linha, não aprovam estes meios de destruição em massa. E passa a analisar as atitudes destes pescadores, sua atenção, sua paciência. E cita medidas sobre a piscicultura, notadamente tomadas na China, como a modificação do curso das águas, a adaptação através de pequenos degraus nas cascatas para os peixes irem em direção à nascente e até de aprisionar o peixe, fecundá-lo de maneira artificial, para aumentar a produção.

Entre os piscicultores existem os que conseguem salvar ovas fecundadas com sucesso. À vista disso, é triste pensar que milhares de crianças que poderiam se transformar em homens perecem no berço por causa da ignorância e da miséria.

Certamente as crianças recém nascidas deveriam nos preocupar mais do que pequenos salmões, carpas e todos os outros possíveis; no entanto, as epidemias atingem em grande quantidade. Nossos hospitais infantis, bem mais preciosos que todos os estabelecimentos de piscicultura, não passam, mais frequentemente, de vestíbulos do cemitério. (RECLUS, 1869, p. 228)

Se um dia conseguirmos domesticar os peixes de água doce, para empregá-los para sustentar a vida humana, isto será um motivo de júbilo.

No capítulo dezesseis (A fábrica e o moinho), diz que incalculáveis riquezas a fábrica gratificou a humanidade e elas podem ser maiores em virtude da força que se sabe retirar dos combustíveis. No entanto, estes produtos deixam normalmente aqueles que 
os fabricam na miséria. Ao lado da magnífica residência senhorial, existem pequenas casas de tijolo escurecidas pelo carvão em um espaço repleto de entulhos e de poças fétidas. Nestas habitações raramente as famílias se reúnem à mesa: ora o marido, ora a mulher, ora as crianças, são chamados pela implacável sirena da fábrica. Se alguma pobre criança fica, é porque está fraca e, cedo ou tarde, uma doença a levará.

E pergunta: esta luta feroz pela existência não terá fim? Será que todos os que se associam para fazer a mesma obra não poderão deixar de gerar desprezo e raiva? Reclus responde à questão que fez: isto não será sempre assim; já começaram as mudanças rumo a uma nova ordem das coisas. O sonho do utópico vai acabar se fazendo a necessidade social e a vontade de todos. $E$ já se pode imaginar:

A fábrica permanece lá; mais do que nunca, ela se tornou um grande laboratório de riquezas; mas esses tesouros não se dividem mais em duas partes, das quais uma é atribuída a um só e a outra, aquela dos trabalhadores, não é senão uma ração miserável; eles pertencem de hoje em diante a todos os trabalhadores associados. Graças à ciência, [...] os operários não serão mais escravos ofegantes da máquina de ferro; após o trabalho do dia, eles têm também repouso e lazer, [...]. (RECLUS, 1869, p. 263)

Para ele, cada geração que morre é seguida por uma diferente, que impulsiona outras. Gerações que se sucederam foram modificando as coisas, a espécie foi melhorando, seu pensamento se tornou mais amplo. E assim terminou o livro:

Os povos se misturam aos povos como os riachos aos riachos, os rios aos rios; cedo ou tarde, eles não formarão mais do que uma só nação, da mesma maneira que todas as águas de uma mesma bacia terminam por se confundir em um só rio. [...] Os povos, tornando-se sábios, aprenderão certamente a se associar em uma federação livre: a humanidade, até aqui dividida em correntes distintas, não será mais do que um único rio, [...]. (RECLUS, 1869, p. 316-317)

Entretanto, esse tempo parece ainda estar distante.

\section{Considerações Finais}

\section{“[...] o tempo modifica continuamente o espaço."}

(Reclus)

81 Com o pensamento impregnado com os ideais de progresso e de noções de higienização, abordou água (do ponto de vista de seu ciclo), bacia, gruta, fontes, corredeiras, meandros, transporte de areias e seixos, matas galerias e sua importância, pesca e extermínio de peixes (com o uso de redes e de veneno) e o papel das cheias na fertilização dos solos. Isso sem deixar de fora temas que lhe eram caros como o uso da água nos desertos, para irrigação, para indústria (embora os que trabalhavam nela estavam comumente na miséria) e a poluição que existia nas grandes cidades, sem deixar de colocar alguns conceitos sobre sua visão de sociedade. 0 riacho agora estava realizando o que antes faziam os escravos de guerra e as mulheres subjugadas por seus maridos.

82 Segundo ele, as fábricas eram um grande laboratório de riquezas, mas estas eram atribuídas em grande parte a uma única pessoa; entretanto, seriam, um dia, de todos os trabalhadores associados (RECLUS, 1869, p. 263).

83 É claro que, em diversas passagens, trazia a marca de sua época, período em que, fora dos grandes centros urbanos, as pessoas ainda possuíam uma familiaridade muito 
grande com a natureza ainda natural. Moinhos hoje são raros e a presença visível do rio em nossas vidas é menor.

Os conceitos geográficos emitidos são muito atualizados; processos sofridos por relevo, erosão fluvial, aluvião, nomes de rochas e de vegetais, águas subterrâneas, exemplos mundiais de rios, lendas da mitologia e outros, são comuns no texto. Críticas ao ensino, à tentativa de impor mentiras como ciência e de modelar cabeças, assim como aos hospitais e às fábricas, também ocorrem.

Este autodidata, que buscou explicar os problemas sociais - e suas soluções - através da Geografia, sem compartimentá-la, foi propositadamente colocado no ostracismo por sua militância anarquista. A sua visão política transparecia em suas obras e nos conceitos que possuía em relação à Geografia.

Sua geografia foi tachada pelos franceses de pré-científica, de somente descritiva; a geografia científica moderna era a fundada por Vidal La Blache (1845-1918). Enquanto a geografia social de Reclus colocava em relevo modos de produção, sistemas de explotação capitalista e de opressão estatista, tipos de propriedade (origem e a justiça de sua posse), processos de povoamento e outros, Vidal, “[...] construiu uma geografia regional embasada na descrição das paisagens e numa geografia humana repousando no estudo dos tipos de vida" (BOINO, 2010a, p. 12).

O que realmente incomodava os integrantes da Escola Regional Francesa era o anarquismo, a concepção inovadora, "sociológica", engajada, de Geografia e as opções pedagógicas de Reclus. Quem fazia análise da religião como ele efetuava, quem evocava constantemente as questões de poder e do Estado, seria contra as pretensões do governo francês e dos conservadores. Para Lacoste, o primeiro grande geógrafo da França foi Reclus; e para "[...] o grande pensador anarquista, a geografia não somente não pode ignorar os problemas políticos, mas ela permite colocá-los melhor, ou revelar a importância dos mesmos" (LACOSTE, 1988, p. 105-106).

De qualquer maneira, Reclus teve o mérito de conseguir fundir seu ideal político com sua práxis profissional. Sua concepção do dinamismo das relações entre o homem e o meio, do dinamismo da organização territorial, da Geografia como um instrumento de transformação da realidade, e da incorporação do papel do Estado e das relações entre as classes sociais como algo essencial da análise geográfica, são concepções fundamentais para a reflexão da Geografia como uma ciência social, como uma ciência a serviço da vida.

Há necessidade de ver se geógrafos terão o desejo de reapossar do pensamento reclusiano para fazer da Geografia um instrumento de compreensão à altura da complexidade do mundo de hoje. 


\section{BIBLIOGRAFIA}

BOINO, Paul. O Pensamento Geográfico de Élisée Reclus. In: RECLUS, Élisée. Da ação humana na Geografia Física; Geografia comparada no Espaço e no Tempo. São Paulo: Expressão e Arte: Editora Imaginário, 2010a, p. 09-39.

HAESBAERT, Rogério. A Nova Orleans de Élisée Reclus e as contradições da "América". GEOgraphia (UFF), Niterói, a. 07, v. 14, p. 113-118, 2006.

KROPOTKIN, Piotr. O Estado e seu papel histórico. São Paulo: Imaginário; Soma; Nu-Sol, 2000, 95 p.

KROPOTKINE, Pedro. A Conquista do Pão. $3^{a}$ ed. Lisboa: Guimarães \& C..$^{a}$ Editores, 1975, 269 p. (prefácio de Elisée Reclus)

LACOSTE, Ives. A geografia - isso serve, em primeiro lugar, para fazer a guerra. Campinas, SP: Papirus, 1988.

RECLUS, Élisée. Histoire d'un ruisseau. Paris: J. Hetzel et Cie.,1869 (Bibliothéque d'Éducation et de Récréation)

. Élisée Reclus: geografia. São Paulo: Ática, 1985.

. O Renascimento. El Hombre y la Tierra, Vol. 4, cap. XI, Casa Editorial Maucci, Barcelona, s/d. Tradução de Ruy Moreira. GEOgraphia - Ano 1 - №. 2 - 1999, p.109-135.

. A evolução, a revolução e o ideal anarquista. São Paulo: Imaginário, 2002. Tradução de Plínio Augusto Coêlho.

. Da ação humana na Geografia Física; Geografia comparada no Espaço e no Tempo. São Paulo: Expressão e Arte: Editora Imaginário, 2010a, 96 p.

. Renovação de uma cidade; Repartição dos Homens. São Paulo: Expressão e Arte: Editora Imaginário, 2010b, 95 p.

. Do Sentimento da Natureza nas Sociedades Modernas. São Paulo: Expressão e Arte: Editora Imaginário, 2010c, 95 p.

\section{NOTAS}

1. Trechos destacados deste livro foram traduzidos do francês pelo autor.

\section{RESUMOS}

O artigo procura analisar História de um riacho (1869), livro escrito pelo geógrafo anarquista Jean Jacques Élisée Reclus. O personagem principal é um pequeno curso d'água, que teve retratado seu percurso da nascente até sua foz no mar. Reclus relaciona a história das nações com a maior ou menor abundância de águas correntes, deixa claro que a água não é composta somente de 
hidrogênio e oxigênio, aborda ciclo da água, bacia, gruta, fontes, corredeiras, meandros, transporte de areias e seixos, matas galerias e outros assuntos, sem abandonar temas que lhe eram caros, como o uso da água para irrigação e indústria, a poluição nas grandes cidades e os conceitos sobre sua visão de sociedade. Os conceitos geográficos emitidos são atualizados e também ocorrem críticas ao ensino, à tentativa de impor mentiras como ciência, assim como censuras a hospitais e fábricas. Ainda emite críticas às ações européias para controlar os rios, ao desvio de águas que transformavam lugares em charcos pestilentos, ao ato de jogar lixo no leito e de transformar rios em esgotos.

Este artículo pretende analizar la Historia de un riachuelo (1969), libro escrito por el geógrafo anarquista Jean Jaques Élisée Reclus. El personaje principal es un pequeño curso de agua, retratado en su recorrido desde su nascimiento hasta su desembocadura en el mar. Reclus relaciona la historia de las naciones con la mayor o menor abundancia de aguas corrientes, déjà claro que el agua no se compone solamente de hidrógeno y oxígeno, aborda el ciclo del agua, hoya, gruta, fuentes, quebradas, meandros, transporte de arenas y guijarros, bosques de ribera y otros asuntos, sin abandonar temas para él importantes, como el uso del agua para la irrigación y la industria, la contaminación en las grandes ciudades y los conceptos de su visión de la sociedad. Los conceptos geógraficos emitidos son actualizados y también aparecen críticas a la enseñanza básica, al intento de imponer mentiras como ciencia, así como censuras a hospitales y fábricas. Además emite críticas a las acciones europeas para controlar los ríos, al desvío de aguas que transforman lugares en charcos pestilentos, al acto de lanzar basura en su lecho y transfomar los ríos en cloacas.

\section{ÍNDICE}

Palabras claves: Élisée Reclus, agua, riachuelo, anarquismo, contaminación

Índice cronológico: 1830-1905

Palavras-chave: Élisée Reclus, água, riacho, anarquismo, poluição

\section{AUTOR}

\section{RUI RIBEIRO DE CAMPOS}

Licenciado em Filosofia e Geografia, professor por 25 anos no ensino médio, Mestre em Educação pela PUC-Campinas e Doutor em Geografia pela UNESP-Rio Claro. É professor da PUC-Campinas de Epistemologia da Geografia, Pensamento Geográfico Brasileiro e Geografia Política. 